\title{
The Effect of Farmers Education on Farm Productivity: Evidence from Small - Scale Maize Producing Farmers in North Bench District, Bench Maji Zone
}

\author{
Habtamu Solomon Korgitet Malkamu Wondimu Biru \\ Lecturer, Department of Economics, Mizan Tepi university, Ethiopia
}

\begin{abstract}
The educational system in Ethiopia is differentiating by low participation rates, particularly in rural areas. The agriculture productivity and income of rural famer is increased by farmer education (formal and informal education). The objective of this study is to examine the effect of farmer education on farm productivity of small-scale maize producing farmers. Cross-sectional data has been collected from 200 maize producing farmers by Semi-Structured questionnaire. Cobb-Douglas production function model has been used to analysis the effect of farm education on farm productivity by including the education level as input of production. The main finding of the study was that higher education contributes to productivity. Extension contact service is also positive effect on farm productivity even though the coverage is very low. Thus, the study conclude that formal schooling opens the mind of farmers to adapt new farm technology, non-formal education propose the farmer to better method of farming, and informal education keeps the farmer on changing ideas among each other. Therefore, this study recommended that to increase their productivity the farmers in the district should have required skills and knowledge in modern farming method and use of modern farm inputs.
\end{abstract}

Keywords: Cobb- Douglas production function model, Education, productivity

DOI: $10.7176 /$ RHSS/9-17-04

Publication date:September $30^{\text {th }} 2019$

\section{Introduction}

In developing countries, agricultural growth is important for poverty reduction because most of people derive their livelihood from agricultural production. Thus, the means of making better agricultural production widely acknowledged as the main strategy for escaping poverty trap (Otsuka and Larson, 2013). The sever problem in Sub Sarah African is productivity is not significantly increased over the decades and its output has not kept speed with population growth (Teklewold, H., et,al, 2013). On the face of it, improving the agricultural technology as a means of increasing farm productivity seems a crucial strategy. According to Ani (2007), improving the farmer's ability for rising agricultural productivity is a pre-requisite for social and economic development for rural areas. This is because agriculture forms the bedrock of economic activities in the rural area. Highest agricultural productivity depends primarily on the education of the rural farmers to understand and accept the complex scientific changes that are difficult for the uneducated rural farmer. Hence, we cannot increase the productivity of the rural farmer without the provision of adult education (Onwubuya, E., 2005).

Hanushek,et,al., (2007) point out three mechanisms through which education may affect economic growth. First, education can increase the human capital (quality of labor) of the labor force, increasing labor productivity and thus transitional growth toward a higher equilibrium level of output (mankiew,et,al., 1992). Second, education can increase the innovative capacity of the economy, which encourages economic growth (Romar, $\mathrm{P}$, 1990), and. Third, education can make possible the diffusion and transmission of knowledge needed to understand and process new information (Benhabib,J and Spiegal, M, 1994).

In the perspective of North Bench district, most of the farmers were illiterate and there is low participation rate of farmers in attending formal education as well as low attention to informal education. There production is famous by low yield as well as returns to farm labor and land is low. This low level of productivity is arising due to several factors, such as small size of farm-holdings, use of traditional farming system and low educational level and training. Thus, to identify the direction of human capital that will important for increasing farmer's productivity, it is significantly essential to investigate the effect of farmer's education on the farm productivity. In addition to that, there is little evidence in the area to suggest that the agriculture, sector's low education level is what affects its contribution to GDP. Thus, this study aims that to identify the effects of farmer education on farm productivity in North Bench District, Bench Maji Zone.

\section{Related Reviewed Literature}

Education is widely believed as an important role in economic growth. At aggregate level, there are strong theoretical reasons for linking the expansion of education to higher rates of economic growth. Agricultural education is the type of education that leads to achievement of practical skills and assist farmers in obtaining and developing skills that would be ultimately transferred to job opportunity in the society (Oduro,O, 2015). The 
productive value of education has two main effects on agriculture: "worker effect" and "allocative effect" (Welch, F, 1970). Worker effect means the farmers with more education are produce more output from a given level of input. Whereas, with allocative effect, a worker is able to acquire information about cost and characteristics of input and interpret the information to make decision that will enhance output. The effect of education on agricultural productivity can also be described as cognitive and non-cognitive as point out by (Appleton, S., \& Balihuta, A. , 1996). A cognitive effect of education comprises basic literacy and numeracy that farmers achieve from education. Concerning non- cognitive effects, there is a change in the attitude of farmers who attend school and this is because of discipline of formal schooling in terms of punctuality, teamwork, correctness, adhering to schedules and so on.

Education is significant input in agricultural production and important input when the firm engaged in activities that involve more complex decision-making (Gallacher, 2001). Knowledge and skills delivery could be an integral part in farmer's capacity to generate higher growth in agricultural productivity (Betz, 2009). The farmers increasing their productivity potential by developing and refining their capablites thourgh education. The more they know about the farming, the more valuable productivity gain (Radcliffe, 2018). Elibariki (2008) using Cobb- Duglas production fuction and sthocastic fronteir model explineing the productivity variation among Smallholder Maize Farmers in Tanziana found that educational level of farmers, access to extension contact service, avialibality of capital and ablity to copy the new farm technology is the factors which causes variation among the small- scale farmers. Therfore, education supports the farmers to facilitate their decision-making, solving problems and learning new technologies.

\section{Methodology}

\subsection{Description of the Study Area}

North Bench District is one from the 10 districts in Bench Maji Zone, SNNPs regional state, located in southwestern part of Ethiopia. Based on the 2007 census conducted by the central statistical agency (CSA), the District has total population of 116,892 of whom men are 579, 32and women are; 58960. The Woreda located about $537 \mathrm{~km}$ southwest of the Addis Ababa. The woreda has located a latitude and longitude of $6.91^{0}-7.2^{0} \mathrm{~N}$ latitude \& $35.53^{0}-35.75^{0} \mathrm{E}$ longitude, and the elevation of the district ranges between $1001-2500 \mathrm{~m}$.a.s.1. The agro-climatic conditions of the district are conducive for the production of various types of crops with cultivable land of 92,165 hector. . Maize occupied the largest cultivated area out of the crops grown in the district.

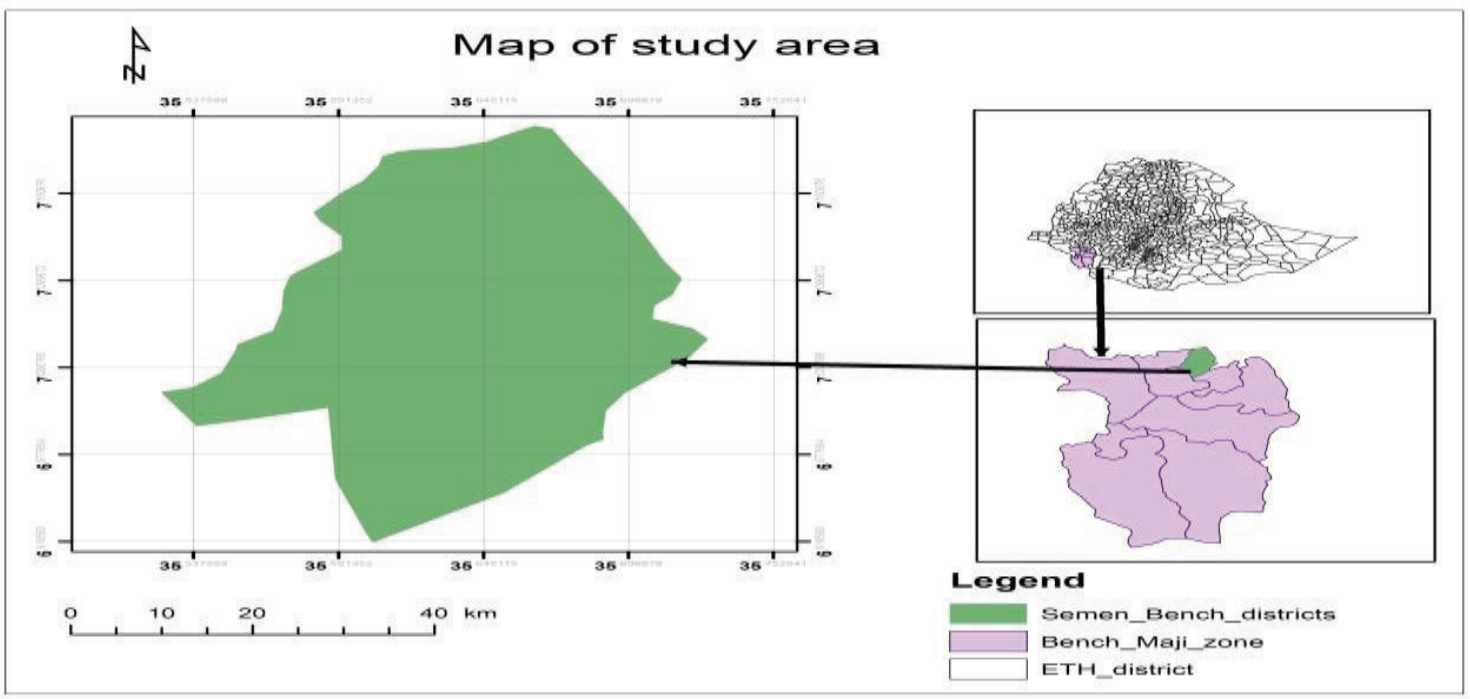

Figure 3.1. Map of the study area

Source: Finance and Economic Development of the district, 2018/19

\subsection{Source, Type and Method of Data Collection}

This study use cross sectional research design in data collection. In conducting the study primary data was collected from farmers basically on the production level, farm size, farm inputs and equipment used, educational level, farming experience, gender, age, secondary occupation, and exposure to extension service. SemiStructured questionnaire was administered, and an interview has conducted for selected farmers.

\subsection{Sampling}

The study uses multi-stage sampling methods. The first stage involves purposively selecting two Keble from 
Nineteen kebeles in the North Bench district because in which high number of maize producing farmers were exists. In the second stage, sample size of 200 maize producing farmers was randomly selected from the total population of 1553 farmers.

\subsection{Method of Data analysis}

Descriptive statistics, such as means, percentage and frequency counts, and standard deviation were used. The study also employs Cobb- Douglas production function model based on the agricultural productivity as the dependent variable. The literature available on the various theories used to explain the effect of education on the farm productivity has mostly focus on the theory of the firm where education is built-in with Cobb- Douglas production function (Weir, 1999; Lockheed et.al, 1980; Edwin, 2001; Oduro, 2015; Murhi 2017). Most of the study using the Cobb- Douglas production function approch state that the functional form of Cobb-Douglas model is assums homoginity, unitary elasticity of subsititution between input and output. By considering all this, to measure the worker effect of schooling, Cobb-Douglas production functions by taking the semi- log linear form were specified as follows:-

$\ln \mathrm{Y}_{\mathrm{i}}=\beta 0+\beta_{1} \ln \mathrm{L}_{\mathrm{i}}+\beta_{2} \ln \mathrm{N}_{\mathrm{i}}+\beta_{3} \ln \mathrm{F}_{\mathrm{i}}+\beta_{4} \ln \mathrm{OXi}+\gamma E_{\mathrm{i}}+\varphi \sum \mathrm{Z}_{\mathrm{i}}+\alpha \sum \mathrm{X}_{\mathrm{i}}+\varepsilon \mathrm{i}$

Where, $\mathrm{Ln} \mathrm{Y}_{\mathrm{i}}$ is the natural logarithm of farm yields' in maize production for household $\mathrm{i}$;

$\ln \mathrm{L}_{\mathrm{i}}$ is the natural logarithm of available cultivable land for household $\mathrm{i}$; $\ln \mathrm{N}_{\mathrm{i}}$ is the natural logarithm of the number of adult household members who work on the farm in household $\mathrm{i}$; $\ln \mathrm{F}_{\mathrm{i}}$ is the natural logarithm of the quantity of fertilizer used by household $\mathrm{i} ; \operatorname{lnOX_{i}}$ is the natural logarithm of the number of bulls and oxen owned by household $\mathrm{i} ; \mathrm{E}_{\mathrm{i}}$ is a variable(s) representing education for household $\mathrm{i} ; \mathrm{Z}_{\mathrm{i}}$ is other household characteristics of household $\mathrm{i} ; \mathrm{X}_{\mathrm{i}}$ is other farm characteristics such as land quality for household $\mathrm{i}$ and $\mathrm{i}$ i is a stochastic error term.

\section{RESULTS}

\subsection{Descriptive results}

This section provides the descriptive analysis on the household head of maize producing farmers in the North Bench District. The section describe the sex, farm experience in maize production, whether they had schooling before or not, land ownership, and exposure to extension service, and the utilization of chemical fertilizer and improved seed.

The result showed that the majority of the respondents were male $(66 \%$,) while the remaining $34 \%$ were female, this implies that majority of the farmers on maize production are males. At least $30.5 \%$ of the surveyed farmers were above 10 years farm experience in maize production, with 38\% in the group of 7-10 years farm experiences and 25\% having 4-6 year experience. The small percentages i.e. $6.5 \%$ of respondents were with less than 3 years experience in maize production. It is believed that they gain experience as they stay on the farm for long. The percentage of maize producing farmers who respond as attending formal schooling was $68.5 \%$. $31.5 \%$ of the sampled farmers were not attending the formal school. This shows most of the maize farmer in the district were not up to basic education. Survey result indicates that $78 \%$ of respondents own land. That means, $22 \%$ of sample farmer did not posses their own land. The farmers who have not own land were produce by renting the land from the relatives and crop sharing with the owner of land. More than 76.5 percent of the maize producing farmers said they has farm assistance from the extension worker and only 23.5 percent of the respondent have no access to contact extension worker. The average number of contacts for all household was 1.54 times per year. This revealed that the individual based number of visits the extension agent to solve the specific problem of farmer was minimal. Extension services provide to improving the farm productivity through informal education of farmers; thus, it needs the intervention of government as well as calls for a careful look of policy makers.

\subsection{Empirical result}

In this part, the researcher analyze that factor affecting farm productivity of small- scale rural maize producing farmers by pleasing 2017/2018 production year as reference. Before speeding up econometric estimation and result display, different econometrics assumptions were tested. To analyze the problem we use the OLS regression and twelve explanatory variables (five continues and seven discrete variable) were hypostasized to influence the productivity of maize farm and take in this analysis. However, take in the final regression analysis, both of the continues and discrete variable needed to be checked for the existence of the multicolliniarity by variance inflated factor (VIF) and contingency coefficient (CC) methods, respectively. Secondly, the inclusion and exclusion of irrelevant and relevant variable respectively were tested by OV (omitted variable) tests. Thirdly, Heteroscedasticity problem were tested by using the Breusch Pagen test (hettest). All the relevant tests for OLS regression model can be seen in annex I

\subsubsection{Variable definition and its mean value}

Table 4.1 shows the data to be used in the production function estimation. Means are expressed for sub sample of observations used in the econometrics analysis. The data estimate the relationship between farmer education and 
farm productivity are from the survey that is drawn from the small-scale maize-producing farmers in the North Bench District, Bench Maji zone. The dependent variable is the natural log the value of maize output in quintal per hectare of land under cultivation. Several of the farm variables is explained in logarithmic form such as cultivated land area under maize production, quantity of fertilizer used, number of oxen the farmers have, and adult members of household.

Table 4. 1 variable definition and its mean value

\begin{tabular}{|c|c|c|c|}
\hline Variable name & Definition & & \\
\hline \multicolumn{4}{|l|}{ Dependent variable: } \\
\hline Ln- maize yields & natural log of value of maize (per hectare) & 1.63 & 0.03 \\
\hline \multicolumn{4}{|c|}{ Farm and household variable: } \\
\hline Ln- $\mathrm{L}_{\mathrm{i}}$ & Natural log cultivated land area under maize production & 0.5 & 0.04 \\
\hline $\operatorname{Ln~} \mathrm{N}_{\mathrm{i}}$ & Natural log of adult member of household & 0.65 & 0.031 \\
\hline Ln $F_{i}$ & Natural log of the amount of fertilizer used & 0.64 & 0.035 \\
\hline $\operatorname{Ln~ox}_{i}$ & Natural log of number of oxen household have & 0.7 & 0.02 \\
\hline Nature of land & Slop of land for the production of maize & 1.99 & 0.08 \\
\hline Age- $\mathrm{HHH}$ & Age of household (years) & 37.5 & 0.05 \\
\hline Fertility of land & Dummy 1 if the land is fertile & 0.44 & 0.035 \\
\hline Sex & Dummy: 1 if the household head is male & 0.72 & 0.03 \\
\hline Secondary occupation & Dummy: 1 if the household head is primly farmers & 1.75 & 0.04 \\
\hline Credit access & Dummy: 1 if the household have credit access & 0.4 & 0.35 \\
\hline \multicolumn{4}{|l|}{ Education variable: } \\
\hline Edu-HHH-F & Years of schooling of household head- farmers & 5.13 & 0.07 \\
\hline Edupri & Dummy: 1 if household head has 1 to 4 schooling & 0.38 & 0.034 \\
\hline Edumid & Dummy: 1 if household head has 5 to 8 schooling & 0.16 & 0.026 \\
\hline Edusec & Dummy: 1 if household head has 9 to 12 schooling & 0.14 & 0.024 \\
\hline Extservi & Dummy: 1 if the household head has extension contact service & 0.32 & 0.033 \\
\hline Larnreletives & Dummy: 1 is the household head has learn from relatives & 0.8 & 0.02 \\
\hline EducNo & Number of household have no schooling & 0.31 & 0.033 \\
\hline
\end{tabular}

Source: survey results, 2018/19

\subsubsection{Effect of farmer education on farm productivity}

This section focuses on the effect of farmer education on the farm productivity. We used education as input of production in our regression, thus the regression is with education variable. The OLS regression and weighted least square estimation were used for the analysis. The estimation in table 4.2 show that the formal year of schooling attended by household head of maize producing farmers as input of maize production and extension service dummy 1-0 as well as learn from relatives, which represents non formal education and informal schooling.

The output elasticity of land size, credit access, number of oxen, nature of land, and sex dummy is positive and statistically insignificant effect up on the productivity of farmers whereas adult household member is negative and insignificant on farm productivity if the specified the regression include the years of schooling completed in both equation i.e. OLS and WLS. The coefficient on the adult household member is rejecting the null hypothesis, this is may be because of those adult members are not devoting their time to support their family or they have may be with another occupation.

The household composition variable age of the household head has positive and significant effect on the maize output in both OLS and WLS at 5\%and 1\% level of significance respectively. Age is proxy of experience of farmers in this analysis. Thus, the older farmers are more experienced in producing maize than the younger farmer. When the age of the farmers increase by one the farmer's productivity was increase by $0.05 \%$, keeping other thing remain constant.

The usage of fertilizer is positive and significant effect on the maize output at $1 \%$ level of significance on OLS regression. One percent increases in the use of modern chemical fertilizer increasers the output of maize by 0.17 percent keeping other variable remaining constant. Similarly, the output elasticity of fertilizer is positive $(0.19 \%)$ and significant at $1 \%$ level of significance on WLS estimation. A study done by Khalil (2015) from Pakistan is also verifying this finding, use of fertilizer increases the fertility of the land that leads to increase in output. The environmental factors land fertility is positive and significant effect at $5 \%$ level of significance on both equations. The result revealed that a one unit improvement in the land quality increase the maize productivity by $0.066 \%$. 
Table 4.2. The OLS and WLS estimate of Cobb- Douglas production function

\begin{tabular}{|c|c|c|c|c|}
\hline & OLS & & WLS & \\
\hline Variable & coefficient & t-ratio & estimation & t-ratio \\
\hline Constant & 0.577 & 2.82 & -0.680 & -0.31 \\
\hline Ln- Li & 0.053 & 1.14 & 0.048 & 0.24 \\
\hline Ln Ni & -0.040 & -0.89 & -0.042 & -0.87 \\
\hline Ln Fi & $0.17 * * *$ & 3.54 & $0.260 * * *$ & 7.06 \\
\hline Ln oxi & 0.105 & 1.74 & 0.086 & 1.27 \\
\hline Age- $\mathrm{HHH}$ & $0.055 * *$ & 2.37 & $0.085 * * *$ & 3.90 \\
\hline Fertility of land & $0.066 * *$ & 1.83 & $0.072 * *$ & 2.00 \\
\hline Nature of land & -0.010 & -0.96 & -0.011 & -1.45 \\
\hline Sex & 0.036 & 0.89 & 0.065 & 1.60 \\
\hline Secondary occupation & -0.037 & -1.08 & 0.012 & 0.37 \\
\hline Credit access & 0.025 & 0.66 & 0.033 & 0.88 \\
\hline Learn from relative & -0.005 & -0.13 & -0.0512 & -0.14 \\
\hline Learn by doing & 0.040 & 0.82 & 0.033 & 0.73 \\
\hline Edupri & $0.178 * *$ & 3.02 & $0.230 * * *$ & 3.58 \\
\hline Edumid & $0.320 * * *$ & 4.72 & $0.301 * * *$ & 4.10 \\
\hline Edusec & $0.472 * * *$ & 7.33 & $0.456 * * *$ & 6.14 \\
\hline Extension service & 0.040 & 0.51 & $0.142 *$ & 1.71 \\
\hline $\mathrm{R}^{2}$ & 0.77 & & 0.95 & \\
\hline Adj- $R^{2}$ & 0.72 & & 0.94 & \\
\hline F- Statistics (prob) & $16.35(0.0000)$ & & $98.44(0.00$ & \\
\hline
\end{tabular}

Source: survey result, 2018/19

Dependent variable is natural log of maize output per hectare. Star indicates significance using a two-tailed test as follows: $* * *=1 \%, * *=5 \% ; *=10 \%$. Natural log of land size is used as the weighted variable.

The worker effect of an additional year of schooling of household head farmer is positive and statistically significant in both OLS and WLS. As shown in the table 4.2 above the result indicate that maize farm productivity increase by $0.17 \%$ when household head farmers completed the 1 to 4 schooling as contrast with the farmers who had not attend any schooling, keeping other thing remain constant. Estimated coefficient of 1 to 4 schooling is positive and statistically significant effect upon maize output at $5 \%$ level of significance. Effect of education dummy variable for maize farmers with 5 to 8 schooling is positive and statistically significant effect at $1 \%$ level of significance. The result reveled that maize farmers who had completed the 5 to 8 schooling were more productive and output per hectare increase by $0.32 \%$ then the no schooling maize farmers. The effect of education dummy 9 to 12 schooling completed is positive and significant effect up on the maize output at $1 \%$ level of significance. Maize productivity of farmers is increase by $0.47 \%$ when the household head completed 9 to 12 schooling as contrasted to farmers who had not attend the formal schooling with keeping other variable remain constant.

In WLS estimation, estimated coefficient of education dummy variable for maize farmers with all formal schooling is positive and significant effect at $1 \%$ level of significance. The maize productivity is increased by $0.23 \%$ when the household head farmer completed 1 to 4 schooling as compared to one who had has no receive formal schooling with all other input remain constant. The famers who had completed 5 to 8 schooling had more productive and output per hector increase by $0.30 \%$ as compare to the farmer who had no schooling. The farmers who receive 9 to 12 schooling has much more productive by $0.45 \%$ than with not schooling farmers.

In summary, farmers who completed the formal schooling have greatly enhanced their farm ability and skill to identify things differently from those with no schooling. The maize producing farmers with the primary schooling is lower productive than with secondary schooling completion. This indicate that secondary education gives the farmers better ability to think critically and take decision that have positive effect in the face other challenges such as weather condition and insufficient funds for input, and hired labour. This contradicts the finding of Kurosaki and Khan (2004), the effect of primary education on crop productivity is significant but additional gain from higher education is very small. The finding is consistent with Reimers (2012) that the return to secondary education is higher than primary education because the ability of farmers to make better decision or choice about combination of input to obtain maximum output is with higher education.

Non- formal education will take in concern extension service. It is crucial for facilitating the spreading of new agricultural technology, their learning and adoption by farmers. The OLS coefficient shows extension service is positive and insignificant effect on maize productivity. In equation two, the extension service is positive and significant effect at $10 \%$ level of significances. This result suggests that the farmers require 
counseling and other service to actively participation on the production of the maize. This result is in line with the finding of Elias et.al., (2015) extension service is the influencing factor in order to enhance the farmer's productivity and it increases the farmer's ability to adopt the new technology as well as modernization.

Informal education used in this study describes the "locality effect" of education whereby farmers split ideas among each other related to their production. The base of the researcher to account learn from relatives is based on participation of farmers in farm based group. The other variable, which is learning by doing, is accounted based on their participation on the field learning. The lower coverage of extension service supplied in the district contributes to the increase in distribution of knowledge among the farmers because that is the voluntarily available source of knowledge in the area. This evidence suggests that if educated farmers are more likely to adopt modern techniques, uneducated neighbors may imitate from them. This imply that, along with own farm education, the education of neighboring farmers and field learning should enter in to household head farm production.

\subsection{Percentage gain per year of education.}

The study computed the percentage increase in output value for one additional year of education of farmers. The percentage increase is obtained by computing the ratio of the output value when the level of education is $1 / 2$ years greater than $\mathrm{E}$, to the value when it is $1 / 2$ less, subtracting one and multiplying by 100 . The percentage increase in output is estimated by using the formula in equation 4.1

$\%$ increase in output $=\left[\frac{e^{\alpha}-1}{N}\right] * 100$

Where, $\alpha$ is the estimated coefficient of education, $e$ is the natural exponential, $\mathrm{N}$ is years of education in the level specified by the dummy variable indicator.

The effect of one year additional schooling is 4.87 percent when the farmer attends 1 to 4 schooling. Similarly, $9.33 \%$ and $15 \%$ change in output when the household attend 5 to 8 and 9 to 12 schooling. See the result in annex III.

${ }^{1}$ The result in equation 4.1 is approving from the method developed by Lockheed., et, al (1980).

\section{Conclusion}

Education can be improving the quality of farmer labour by enabling them to produce more with their available stock of production factors. Moreover, it can help farmers to choose way that is more effective to production by adopting new technology and increase the efficiency of the resource allocation. In order to understand the effect of farmer education on the farm productivity, this study estimated and quantifies the contribution of formal schooling attended, exposure to extension service, and learns from relatives on the maize productivity of farmers. Cobb- Douglas production function has specified with education variable as input of production. Due to Heteroskcadacity problem, the study employs the weighted least squares method in estimation this is because the Heteroskcadacity causes the OLS estimator inefficient. However, the OLS estimation results are reported after the transformation. Formal years of schooling completed by the household head farmers had significant and positive effect on the farm productivity. The result exposed that the additional year of schooling causes high productivity. schooling tend to enhance the farm efficiency by providing the skills enabling them to achieve higher output for a given input, enhance the farmer ability to obtain, understand, and utilize the new inputs and practices, and improve the overall farmer manageable performances. The education is significantly increasing the probability of adopting the new and matured technologies, and acquire information from extension by talking with extension agent personally and attending the meeting about the use of new input and procedure subsidize by the extension agent.

\section{Recommendation}

Based up on the finding of the study, the following point need to be considered as possible recommendations:-

- Inclusion of education at the core of rural development and food security agenda focusing on expanding access to education and improving school attendance of farmers in the districts, and finding the appropriate ways to integrate agriculture in the basic education curriculum.

- Government investment in agriculture should be guide towards the provision of better extension service. The minister of agriculture should transfer more extension agents to the districts and provide them with motor bicycle to facilitate easy movement among the Keble's. In addition, various farmers also confused to utilize the extension service offered; hence, extension agents should be trained to practice evidence based teaching.

- Sampled farmers complained about the continues increase in the price of fertilizer and the low access to 
credit in the district. Thus, providing the access to credit and subsidize the fertilizer to unable farmers' is one of the possible solutions.

- Focus on the way by which knowledge of farmers can be improved. The way through which this can be done is through adult literacy classes. In addition, the non-formal section of the education director can be train basic schoolteachers and other literacy in the district to grasp the classes and tech the illiterates.

- It is suitable to conclude that the farmers can achieve productivity if the farmers with certain level of education are assisted to increase their efficiency in production. Thus, to increase their productivity the farmers in district should have required skills and knowledge in modern farming method and be able to know simple instruction on the use of modern farm inputs.

\section{Reference}

Abbasian, T. H. (2011). Impact of educated farmer on Agricultural Product . Journal of Public Administration and Governance, Vol. 1, No. 2 .

Adhikari, D. (2016). Extension Service and Farm Productivity in Nepalese Agriculture . Working Paper .

Afari, e. (2001). the effect of farmers' education on farm productivity and income in ghana: implication for food security. university of ghana.

Agriculture, and Rural Development office. (2018).

Alene, A. D. (2007). The Effects of Education on Agricultural Productivity under Traditional and Improved Technology in Northern Nigeria: An Endogenous Switching Regression Analysis. Empirical Economics ,32, 141-159.

Amin \& Awung. (2005). Economic Analysis of returns to priavate invsetment in education in cameroon. peper persented on thr regional conference on education in West Aferica: conistrantes and oppurtunity, (pp. 2526). Dakar, Senigal.

Anderson, J. R. ( 2004). Agricultural extension: Good intentions and hard realities. The World Bank Research Observer, 19(1) , 41-60.

Ani. (2007). A pathway for sustanable agricultural development. costain, Kaduna: Apani publication.

Appleton, S., \& Balihuta, A. . (1996). Education and Agricultural Productivity: Evidence from Uganda. . Journal of International Developement , 8 (3), , 415-444.

Asadullah, M \& Rahman, S. (2005). Farm productivity and efficiency in rural Bangladesh: the role of education revisited.

Asfaw, A., \& Admassie, A. (2004). The role of education on the adoption of chemical fertilizer under different socio economic enivieronoment in ethiopia. journal of Agricultural economics, 30 , 21 5-228.

Barro, R. a.-W. (2015). Education Matters: Global Schooling Gains from the 19th to the 21st Centur. New York, NY: Oxford University Press.

Barro, R. J.-W. (2010). "A new data set of educational attainment in the world, 19502010." NBER Working Paper 15902.

Benhabib,J and Spiegal, M. (1994). The role human capital in economic developement: Evedance from aggregate cross- country data . Jouranal of Monetary Economics, 34 , 143-173.

Betz, M. (2009). The effectiveness of agricultural extension with respect to farm size: the case of Uganda. In Paperprovidedby Agricultural and A p plied Econo m i c s Association in its series 2009 Annual Meeting.

Byrd, M. W. (2016). Education, Economic Growth, and Social Stability: Why the Three Are Inseparable.

Chaudhri, D. P. (1979). Education, Innovations and Agricultural Development:. A Study of Northern India (London: Croom Helm Ltd. for the International Labour Organisation). .

Colclough, C. (1980). "Primary Schooling and Economic Development: A Review of the Evidence. World Bank Staff Working Paper No.399.

Cotlear, D. (1986). "Farmer Education and Farm efficiency in Peru: The Role of Schooling,. EDT Discussion Paper 49 .

Elibariki E. MSUYA, S. H. (2008). Explaining Productivity Variation among Smallholder Maize Farmers in.

Gallacher, M. (2001). Education as an Input in Agricultural Production: Argentina . JEL Classification: D24, Q12.

Gasperini. (2000). Sustainable Development Department, Food and Agricultural Organization of the United Nations.

Hanushek,et,al. (2007). Education quality and economic growth. Washington: world Bank.

Kilonizi, S. (2011). Maize production and it implication on food security for small scale farmers in Keneya.

Knight, J. S. (2003). The Role of Education in Facilitating Risk-taking and Innovation in Agriculture. Journal of Development Studies , 1-22.

Kotze, D.A., . (2003). . Role of women in the household economy, food production and food security. Outlook on Agriculture, 32 , 111-121. 
Luh, F.-M. H.-H. (2009). The Economic Value of Education in Agricultural Production: A Switching Regression Analysis of Selected East Asian Countries. Contributed Paper prepared for presentation at the International Association of Agricultural Economists Conference. Beijing.

Marconi, G. (2012). Education and growth with learning by doing . Conference of the Scottish Economics Society. Perth : Maastricht.

Moock, P. (1994). "Education and Agricultural Productivity". International Encyclopaedia of Education , $244-$ 254.

Murhi, M. e. (2017). Education and Agricultural Productivity in Democratic Republic of Congo: The Case of South-Kivu Province. International Journal of Elementary Education , 7(1): 7-12.

Nowak.a, g. d. (2016). the contribution of education to economic growth: evidence from nepal. international journal of economic sciences .

Oduro,et,al. (2014). effects of education on the agricultural productivity of farmers. international journal of development research, 1951-1960.

Okpachu, a. et,al. (2014). the impact of education on agricultural productivity of small scale rural female maize farmers in potiskum. international journal of research in agriculture and food sciences .

Onphanhdala, P. (2009, January). Farmer Education and Agricultural Efficiency: Evidence from Lao PDR. GSICS Working Paper Series .

Onwubuya, E. . (2005). Social Educational Psychology in Extension, in Adedoyin, S. F (ed) Agricultural Extension in Nigeria. AESON.

Otsuka and Larson. (2013). Towards a green revolution in sub- sharan Africans. In An African Green Revolution, 281-300.

Owens, T. H. (2003). The impact of agricultural extension on farm production in resettlement areas of Zimbabwe. Ec o no mic Devel op me n tand Cult u r a l change,51 (2), ,337-357.

Radcliffe, B. (2018). How Education and Training Affect the Economy.

Reimers, M. \&. (2012). Revisiting the Role of Education for Agricultural Productivity. American Journal of Agricultural Economics, 95 (1), , 131-152.

Sumner, A. . (2012). ). Where do the world's poor live? A new update. IDS Working Papers, 2012(393, 1-27.

Sylvie. K, e. (2017). The impact of education on Economic Growth : In case of India. ACTA UNIVERSITATIS AGRICULTURAE ET SILVICULTURAE MENDELIANAE BRUNENSIS .

Teklewold, H., et,al. (2013). Adoption of multiple sustaniable agricultural practice in ethiopia. Journal of Agricultural Economics, 64(3), , 597-623.

weir. (1999). The Effects of Education on Farmer Productivity in Rural Ethiopia. Oxford: Centre for the Study of African Economies, Department of Economics, . University of Oxford.

Welch, F. (1970). Education in Production. Journal of Political Economy, 78 (1) , 35-59.

ANNEX I: Testes for Multicolliniarity and Model specification

1a. Multicolliniarity

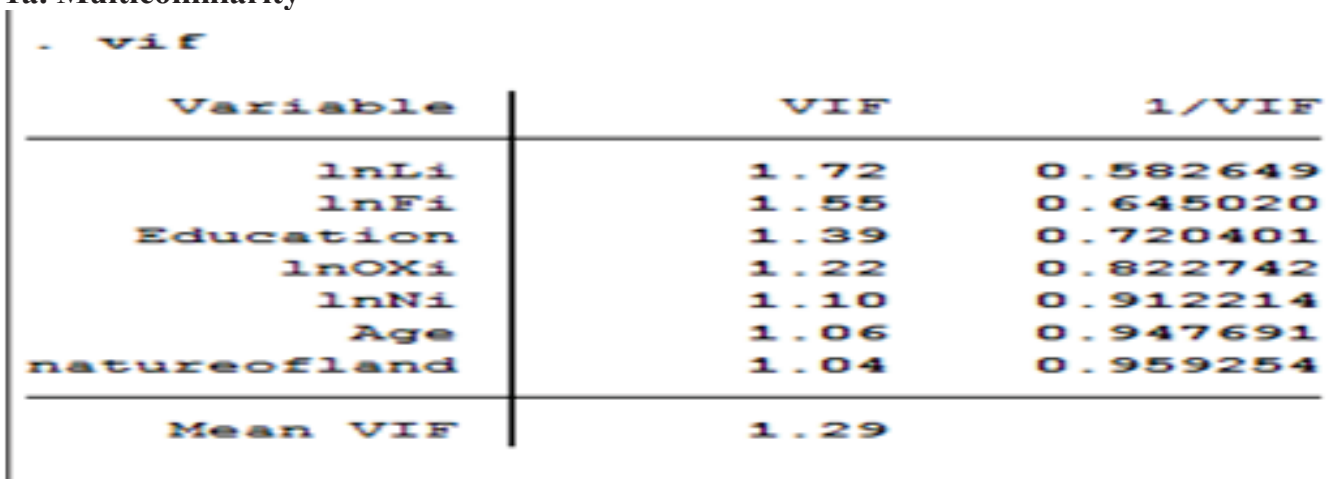

1b. Model specification

ovtest

Ramsey RESET test using powers of the fitted values of lnYi

Ho: model has no omitted variables

$E(3,75)=2.20$

Prob $>F=0.0946$ 
ANNEX II: Econometrics Result OLS regression

\begin{tabular}{r|ccc} 
Source & ss & df & MS \\
\hline Model & 5.59671587 & 16 & -349794742 \\
Residual & 1.64768378 & 77 & -021398491 \\
\hline Total & 7.24439965 & 93 & .07789677
\end{tabular}

$\begin{array}{llr}\text { Number of obs } & = & 94 \\ \text { F } 16, \quad 77) & = & 16.35 \\ \text { Prob }>\text { F } & = & 0.0000 \\ \text { R-squared } & =.7726 \\ \text { Adj R-squared } & =0.7253 \\ \text { Root MSE } & =14628\end{array}$

\begin{tabular}{|c|c|c|c|c|c|c|}
\hline $\ln Y i$ & Coef. & Std. Exr. & $t$ & $P>|t|$ & [958 Conf. & Interval] \\
\hline $\ln L_{i}$ & .053547 & .047042 & 1.14 & 0.259 & -.0401256 & -1472195 \\
\hline $\ln \mathrm{Ni}_{i}$ & -.0405034 & .0456211 & -0.89 & 0.377 & -.1313466 & .0503399 \\
\hline $\ln F i$ & -1618723 & .0457457 & 3.54 & 0.001 & .0707809 & .2529637 \\
\hline $\operatorname{lnox} i$ & .1050851 & .0602556 & 1.74 & 0.085 & -.0148992 & .2250694 \\
\hline Age & .0544457 & .0229433 & 2.37 & 0.020 & .0087598 & -1001316 \\
\hline $\operatorname{sex}$ & .0365369 & .0411091 & 0.89 & 0.377 & -.0453219 & -1183956 \\
\hline creditAccess & .025251 & .0383621 & 0.66 & 0.512 & -.0511377 & .1016397 \\
\hline landfertility & .0660298 & .0361338 & 1.83 & 0.072 & -.0059218 & -1379814 \\
\hline natureofland & -.0105528 & .0110063 & -0.96 & 0.341 & -.0324692 & .0113636 \\
\hline secondaryoccopation & -.0378244 & .0349325 & -1.08 & 0.282 & -.1073838 & .031735 \\
\hline learnfromrelative & -.005011 & .0396356 & -0.13 & 0.900 & -.0839355 & .0739136 \\
\hline Extensionservice & .0406412 & .0804001 & 0.51 & 0.615 & -.1194559 & .2007382 \\
\hline learnbydoing & .0405721 & .0497629 & 0.82 & 0.417 & -.0585185 & -1396627 \\
\hline Edupri & .1789926 & .0593485 & 3.02 & 0.003 & .0608147 & .2971704 \\
\hline Edumid & .3200811 & .0678054 & 4.72 & 0.000 & -1850634 & .4550989 \\
\hline Edusec & -472187 & .0644501 & 7.33 & 0.000 & -3438504 & .6005236 \\
\hline _cons & .5776416 & .2047052 & 2.82 & 0.006 & .1700215 & -9852618 \\
\hline
\end{tabular}

\section{WLS estimation}

\begin{tabular}{r|ccc} 
Source & ss & df & MS \\
\hline $\begin{array}{r}\text { Model } \\
\text { Residual }\end{array}$ & 54.3202471 & 16 & 3.39501544 \\
2.65553012 & 77 & .034487404 \\
\hline Total & 56.9757772 & 93 & .612642766
\end{tabular}

$\begin{array}{llr}\text { Number of obs } & = & 94 \\ \text { F }(16, \quad 77) & = & 98.44 \\ \text { Prob }>\text { F } & =0.0000 \\ \text { R-squared } & =0.9534 \\ \text { Adj R-squared } & =0.9437 \\ \text { Root MSE } & =.18571\end{array}$

\begin{tabular}{|c|c|c|c|c|c|c|}
\hline yii & Coef. & Std. Err. & $t$ & $P>|t|$ & [95\& Conf. & Interval] \\
\hline $1 i 2$ & .0481635 & .1991429 & 0.24 & 0.810 & -.3483807 & .4447077 \\
\hline $\mathrm{Ni} 2$ & -.0423964 & .0487773 & -0.87 & 0.387 & -.1395244 & .0547315 \\
\hline Fi2 & .2604175 & .036905 & 7.06 & 0.000 & .1869303 & .3339047 \\
\hline Oxiz & .0867808 & .0681985 & 1.27 & 0.207 & -.0490198 & .2225814 \\
\hline age 2 & .0854363 & .0218845 & 3.90 & 0.000 & .0418587 & .1290138 \\
\hline $\operatorname{sex} 2$ & .0658751 & .0411016 & 1.60 & 0.113 & -.0159687 & .1477188 \\
\hline crdit2 & .0337901 & .0384057 & 0.88 & 0.382 & -.0426855 & .1102656 \\
\hline exte 2 & .1429544 & .0835646 & 1.71 & 0.091 & -.0234439 & 3093528 \\
\hline frtility2 & .0727253 & .0363439 & 2.00 & 0.049 & .0003553 & .1450952 \\
\hline $\mathrm{N} 1$ and2 & -.0164822 & .0114021 & -1.45 & 0.152 & -.0391866 & .0062223 \\
\hline secoco 2 & .0123534 & .0333856 & 0.37 & 0.712 & -.0541259 & .0788327 \\
\hline learnreltvs2 & -.0051761 & .037887 & -0.14 & 0.892 & -.0806187 & .0702665 \\
\hline learndoing 2 & .033812 & .0462723 & 0.73 & 0.467 & -.058328 & .1259521 \\
\hline edupriz & .2309677 & .0645815 & 3.58 & 0.001 & .1023695 & .3595659 \\
\hline edumid2 & .3014668 & .0735543 & 4.10 & 0.000 & .1550015 & .4479322 \\
\hline edusec2 & -4566903 & .0743778 & 6.14 & 0.000 & .3085851 & .6047955 \\
\hline _cons & -.0990241 & .324404 & -0.31 & 0.761 & -.7449951 & .5469468 \\
\hline
\end{tabular}

\section{Annex III}

Table 4.3. The percentage increase in output related with an extra year of schooling of household head farmer.

\begin{tabular}{|l|l|}
\hline Educational variable & Percentage increase in output \\
\hline Primary (1 to 4 schooling) & 4.87 \\
\hline Middle ( 5 to 8 schooling) & 9.33 \\
\hline Secondary ( 9 to 12 ) schooling & 15 \\
\hline
\end{tabular}

Source: author computation from survey (2018/19), using the formula developed by Lockheed (1980)

- $\quad$ Result is based on equation 4.1 